\title{
KEDUDUKAN ULAMA, UMAT ISLAM, DAN KEMUNCULAN HALUAN KIRI DALAM REVOLUSI SOSIAL DI KABUPATEN BREBES 1945
}

Oleh: Aman

(Universitas Negeri Yogyakarta)

email: aman@uny.ac.id

\begin{abstract}
ABSTRAK
Penelitian ini bertujuan untuk mengetahui bagaimana eksistensi ulama dan umat Islam dalam dalam revolusi sosial di Kabupaten Brebes tahun 1945, kemunculan haluan kiri yang menyertai revolusi sosial tersebut. Metode penelitian berasal dari kata method dalam bahasa inggris yang berarti Metode yang digunakan peneliti dalam penulisan sejarah ini adalah metode penelitian menurut Kuntowijoyo. Adapun tahapan penelitian sejarah menurut Kuntowijoyo mempunyai lima tahap yaitu pemilihan topik, heuristik, verifikasi, interpretasi, dan penulisan. Hasil Penelitian menunjukkan bahwa kedudukan ulama dan umat Islam di Kabupaten Brebes mempunyai posisi yang strategis dan menjadi pengarah yang baik jalannya revolusi. Sedangkan kemunculan kelompok kiri dalam revolusi sosial menjadi penyulut revolusi itu sendiri dan menampilkan pergerakan bahwa seolah-olah kelompok sosial inilah yang memiliki peranan penting dalam melawan penindasan dan perlawanan terhadap status quo. Hal inilah yang selanjutnya memicu permusuhan antara ulama dan kelompok kiri.
\end{abstract}

Kata Kunci: ulama, umat Islam, haluan kiri, revolusi sosial di Brebes.

\section{A. Pendahuluan}

Untuk memahami duduk persoalan tentang eksistensi dan keterlibatan rakyat Kabupaten Brebes dalam revolusi sosial di tiga daerah, atau lebih dikenal dengan Peristiwa Tiga Daerah, maka perlulah kiranya dilberikan gambaran umum tentang peristiwa tiga daerah itu sendiri. Ketiga daerah tersebut adalah Kabupaten Brebes, Tegal dan Pemalang yang semuanya itu berada di wilayah Karesidenan Pekalongan.

Pada bulan oktober 1945, masyarakat di daerah Karesidenan Pekalongan dikejutkan oleh pergerakan rakyat yang mengadakan gerakan pemberhentian pejabat pemerintah setempat secara pakasa. Gerakan ini terkenal dengan "Aksi 
Pendaulatan”. Yang menjadi sasaran aksi ini terutama para lurah, camat, wedana, bupati, atau para pejabat pemerintah lainnya. Secara beramai-ramai pendukung aksi ini datang ketempat korban untuk menangkap dan mengadilinya. Hasil setoran padi paksa di jaman Jepang, yang pada waktu itu menumpuk di Kumiai dan penggilingan-penggilingan padi beserta bahan-bahan tekstil, merupakan perangsang bagi rakyat yang sudah lama menderita kelaparan dan hanya dapat memakai pakaian karung goni untuk melakukan balas dendam terhadap pejabat setempat. ${ }^{1}$ Setelah segala kesalahan dituduhkan, si korban dinyatakan diberhentikan dari jabatannya dan penggantinya segera ditunjuk. Bagi yang bernasib sial, bukan jabatannya yang dicopot, tetapi ;nyawanya ikut dicopot pula. Aksi ini dilancarkan dan dibarengi keributan dan keonaran. Sesungguhnya keributan semacam ini melanda hamper di seluruh daerah di Karesidenan Pekalongan.

Keonaran yang paling menonjol yang terjadi di Karesidenan Pekalongan ini, adalah yang melanda tiga daerah kabupaten, yaitu Kabupaten Brebes, Tegal dan Pemalang. Arus dan gejolak revolusi yang terjadi di tiga Kabupaten ini lebih dikenal dengan Peristiwa Tiga Daerah. Di ketiga daerah yang terletak di pesisir utara Jawa Tengah bagian barat ini, kericuhan-kericuhan dan gejolak semacam ini banyak membawa korban. Pendaulatan terhadap lurah dan camat, perampokan dan perampasan rumah pejabat serta isinya dan pembakaran-pembakaran yang dilakukan oleh massa, mewarnai tiga daerah di Karesidenan Pekalongan ini. ${ }^{2}$

\footnotetext{
${ }^{1}$ Kodam VII Diponegoro, Sedjarah TNI-AD, Sirnaning Jakso Katon Gapuraning Ratu, Semarang: Dinas Sejarah Militer Kodam VII/ Diponegoro, 1971, hlm. 58

2 Sartono Kartodirdjo, Wajah Revolusi Indonesia dipandang dari Perspektivisme Struktural. Prisma, No. 6. Jakarta: LP3ES, 1962, hlm. 13
} 
Di Kabupaten Brebes, yang letaknya disebelah barat Kabupaten Tegal, gejolak revolusi juga terjadi dimana-mana. Sulitlah menentukan dimana sebenaqrnya mula-mula terjadi aksi massa ini. Namun diperkirakan bahwa pergolakan di Kabupaten Brebes ini, dimulai disekitar pabrik gula Banjaratma, di bagian tengah Kabupaten ini. $^{3}$ Disinilah gelombang keonaran yang paling menonjol di Kabupaten Brebes. Pergolaka dimulai dengan pembakaran kandang babi dan kemudian serangan terhadap pabrik gula serta pembunuhan terhadap orang-orang indo. ${ }^{4}$

Gejolak revolusi terus menjalar keluar Ibu Kota Kabupaten. Di desa-desa timbul gelombang keonaran, dengan melakukan pencurian dan pembakaranpembakaran. Padi-padi yang menumpuk di Kumiai dan dipenggilinganpenggilingan diambil paks oleh massa secara beramai-ramai. ${ }^{5}$ Bahkan banyak pegawai Kumiai yang tindakannya semasa pendudukan Jeaspangkurang berkenan dihati rakyat, didombreng dan dipermalukan. Seperti halnya di Kecamatan Salem, pegawai Kumiai (pengumpul padi) didombreng dengan leher diberi kalung padi. ${ }^{6}$ Sedangkan di Krasak, Kecamatan Brebes, Amran Lurah lama yang terkenal sebagai penindas di masa pendudukan Jepang, pernah mengirim 50 romusa yang tidak pernah kembali lagi, mengambil 400 kuintal padi dari lumbung desa dan masih banyak lagi tindakan pemerasan terhadap rakyatnya, dikejar-kejar massa untuk dibunuh beramai-ramai. Namun atas jasa ketua KNI desa yang baru dipilih,

${ }^{3}$ Suryo, op. cit., hlm. 80. Didalam tulisan Djoko Suryo disebutkan bahwa Banjaratma terletak di Kabupaten Brebes bagian Selatan. Tetapi sebenarnya Banjaratma itu terletak di bagian tengah Kabupaten Brebes.

${ }^{4}$ Kartodirdjo. Op. cit., hlm. 8.

${ }^{5}$ Darsam al-Martoni, wawancara, 30 Mei 1998

${ }^{6}$ Cakrameja, wawancara, 27 Maret 1999. 
upaya pembunuhan kepada Amran dapat dicegah. Akhirnya Amran beserta pengikutnya diturunkan dari jabatannya kemudian digantikan Karto, seorang lenggaong yang pernah bekerja sebagai pengawas romusa semas pendudukan Jepang.

Secara relatif, perkembangan revolusi sosial dan perubahan pemerintah di Kabupaten Brebes, berlangsung lebih lunak jika disbanding dengan daerah Tegal dan Pemalang. Tidak seorang camat pun terbunuh di Kabupaten ini. Penguasa lamditumangkan tanpa kekerasan yang dahsyat. ${ }^{7}$ Bila pejabat baru ternyata pernah terlibat dalam penindasan ekonomi Jepang dan dukungan rakyat tidak kuat, maka ia akan segera diganti. Sebagai contoh camat Banjarharjo, ia mengangkat dirinya sebagai wedana setelah memaksa wedana lama menyingkir ke luar daerah. Tetapi wedana baru ini tidak diterima oleh para pemimpin Islam setempat, karena hubungannya rapat dengan Jepang, sehingga ia didaulat untuk ke luar daerah setelah dua minggu memegang jabatan wedana. ${ }^{8}$

Dai Ketanggungan Barat, yaitu disebelah utara Banjarharjo, terdapat bekas tanah partikelir. Ketika tenctara Jepang datang, wedana diganti dan tanah itu digunakan untuk penanaman tebu oleh pemerintah Jepang. ${ }^{9}$ Ketika revolusi sosial telah bergolak, didaerah ini juga banyak terjadi kericuhan-kericuhan. Pemuda Pesindo yang radikal menggunakn pabrik gula sebagai markasnya, dan memasang tanda "milik Negara".

Di Kawedanan Bumiayu, pergantian wedana dan para camatnya berlangsung tanpa kekerasan, ketika datang keputusan dari Brebes yang

\footnotetext{
${ }^{7}$ Kartodirdjo, op. cit., hlm. 8

${ }^{8}$ Supratikno, wawancara, 29 Maret 1999

${ }^{9}$ Ibid.
} 
memberitahu bahwa wedana dan para camatnya akan dibebastugaskan, maka mereaka langsung mengundurkan diri dari jabatannya. ${ }^{10}$ Sedangkan di daerah Losari, bagian barat laut perbatasan Brebes, para santri menempatkan orang-orang Islam yang tidak bersembahyang lima waktu ke dalam usungan jenazah. Bagaiman dengan pergolakan yang terjadi di kota kabupaten. Mari kita amati jalannya revolusi sosial di kota Brebes ini. Selama pergolakan sosial pada bulan Oktober, hubungan antara ibukota kabupaten dengan desa-desa di daerah pedalaman menjadi semakin sulit. Banyak orang takut bepergian keluar kota, karena khawatir akan diculik dan kehilangan nyawa. Apalagi jalan-jalan yang menghubungkan desa-desa pedalaman kekabupaten banyak melewati hutanhutan. ${ }^{11}$ Ada beberapa pangreh praja yang berhasil meloloskan diri, ada pula yang tidak diketahui bagaimana nasibnya. Banyak camat melarikan diri ke ibu kota kabupaten dan karesidenan pekalongan, tetapi pergolakan sosial tampaknya mengejar pangreh praja sampai ke ibu kota karesidenan.

Pengumuman bahwa tentara sekutu akan menduduki Jawa pada waktu singkat telah melibatkan bupati ke medan pertikaian terbuka dengan kaum revolusioner di Brebes. Walaupun pada akhirnya Bupati menerima kemerdekaan Indonesia, keragu-raguan terhadap pangreh praja, yang oleh pemuda Brebes Sugeng Hargono dinamakan kelompok Mosvia, itu tetap berlanjut. Penentangan pangreh praja terhadap gerakan revolusioner timbul dalam berbagai cara, di samping BKR (badan keamanan Rakyat)/ TKR (tentar Keamanan Rakyat) resmi yang di bentuk pada bulan September di Brebes maka wedana Brebes $\mathrm{R}$.

\footnotetext{
${ }^{10}$ Darsam al-Martoni, Wawancara, 30 Mei 1998

${ }^{11}$ T. Suhandan, Wawancara, 30 Maret 1999
} 
Sudirman membentuk "BKR gelap" yang rupa-rupanya digunakan untuk melindungi pangreh praja. Ketua KMI Brebes, Kartohargo, dalam siding pengadilan mengatakan bahwa BKR gelap ini terdiri dari bajingan-bajingan yang tidak di sukai rakyat, karena merasa dekat dengan pangreh praja mereka sering berlaku tidak adil.

Selain AMRI (Angkatan Muda Republik Indonesia) Brebes pimpinan Kartohargo, beberapa pemuda bersama beberapa lenggaong membentuk AMRI-1 (Angkatan Muda Republik Indonesia Islam). Mereka itulah yang terlibat dalam pertentangan dengan BKR/TKR dan AMRI Brebes. Mereka menganggap bahwa AMRI Brebes merupakan cabang AMRI Slawi, dan menguasai sebuah penggilingan padi. BKR/TKR resmi diakui oleh AMRI-1 sebagi kelompok pemuda nakal yang islamnya tidak sungguh-sungguh. ${ }^{12}$

Dalam menaggapi situasi sosial yang semakin memburuk, patih Brebes datang ke kantor KNI membawa surat dari bupati, yang mengatakan bahwa semua pangreh praja bersedia meletakan jabatan kalau rakyat tidak menghendaki mereka. ${ }^{13}$. bupati meminta KNI mencabut pernyataan dan diumumkan di depan rapat para pemimpin rakyat yang diselenggarklan oleh Kartohargo selaku juru penerang KNI. Rapat KNI Brebes ini di kacau oleh pemimpin AMRI-1. Kartohargo menegaskan bahwa sekalipun mereka dalam revolusi, tetapi jangan main hakaim sendiri jika ingin menggati pejabat, teruskanlah keinginan itu melalui KNI. Mukhsan menjawab bahwa dialah yang berkuasa di Brebes bukan

12 Anton E. Lukas, "The Bamboo Spears Pierces the payung: the revolution against the beurecratic alite in nort central java in 1945", alih bahasa pustaka utama graffiti, peristiwa tiga daerah: revolusi dalam revolusi. Jakarta: pustaka utama graffiti, 1989, hlmn 222.

${ }^{13}$ Kartodirdjo, op.cit., hlm.8. 
Kartohargo. Wedana Brebes berusaha melindungi Mukhsan yang mempunyai wibawaa besar di pasar Batang. Tokoh AMRI-I ini diharapkan dukungannya kepada wedana yang semakin tersisih dari kalangan perjuangan. Wedana Soedirman meminta agar Kartohargo membebaskan Mukhsan yang hendak ditangkap. Wedana juga menyarankan kepada kepala kepolisian kabupaten, tetpi polisi juga menahan orang-orang AMRI-I lainya, karena pembunuhan terhadap orang-orang Indo di Jatibarang. Mukhsan melarikan diri, kemudian ia ditangkap kembali oleh PKN (penjaga keamanan Negara) yang terbentuk pada minggu kedua bulan Oktober untuk menggantikan kepolisian lama. Kemudian ia dibawa keasrama PKN, dan kemudian dikirim ke penjara Tegal ${ }^{14}$.

Tawaran bupati kepada pangreh praja Brebes untuk meletakkan jabatan ternyata sudah terlambat. Ketegangan di kota Brebes semakin menjadi. Pada tanggal 18 oktober malam, Bupati Sarimin Reksadihardja, patih palal pranoto, dan sejumlah vedana (antara lain slamet wedana Tanjung, dan Soedirman Danoewilogo, wedana Brebes) adalah orang yang diculik dan dibawa ke suatu tempat di Tegal Selatan. ${ }^{15}$

Pada tanggal 21 oktober mereka dibawa ke markas API (Angkatan Pemuda Indonesia) Tegal dan dua hari kemudian dibawa ke sebuah perkebunan milik orang Indo yang teclah dilbunuh bebearapa hari sebelumnya. Di sinilah mereka bertemu densagan pangreh praja lainnya. Setelah dilakukan pemeriksaan, sepuluh hari kemudian, para pangreh praja itu diambil, dan dibawa kembali ke penjara Tegal. Patih, wedana Tegal, sekretaris Kabupaten, serta dua orang pejabat

\footnotetext{
${ }^{14}$ Lukaas, op.cit., hlm.223.

${ }^{15}$ Suryo, op. cit., hlm. 74
} 
lainnya atas nasehat KNI berl;indung do penjara, yang merupakan satu-satunya tempat yang aman bagi mereka. Tetapi nyatanya pemerintah karesidenaan Pekalongan dan tentara menuduh kaum revolusioner telah memenjarakan para pejabat. Hal ini disebabkan karena mereka berada di penjara bersama dengan pangreh praja Brebes yang diculik. Tetapi kemudia barisan pelopor menjelaskan bahwa para pejabat itu tinggal di penjara karena meresa tidak aman tinggal di tempat lain. ${ }^{16}$ Pada waktu itu memang penjara benar-benar merupakan tempat yang aman untuk berlindung dari amukan massa.

Akibat aksi-aksi pendaulatan, maka timbulah kekosongan kekuasaan. Pemerintah boleh dikatakan lumpuh. Alat keamanan tak berdaya, dan alat pemerintahan 1;ainnya hamper tidak berfungsi lagi. Ini terjadi karena banyak jabatan pemerintahan yang lowong. Dalam keadaan darurat pengisian lowongan jabatan segera dilakukan, meskipun tidak menurut prosedur administrative yang legal-rasional sebagaimana mestinya. Satu hal yang cukup menarik adalah bahwa jabatan bupati di Brebes dan Tegal diisi dengan menunjuk pemuka agama yang berpengaruh di daerah masing-masing. Kyai Haji Syatori ditunjuk untuk menjabat Bupati Brebes. Sedangkan Kyai Abu Suja'I, pemuka agama yang berasal dari Desa Pacul, Tegal Selatan, ditunjuk menjadi Bupati Tegal. Hanya di Pemalang jabatan Bupati dipegang oleh orang yang bukan pemuka agama yaitu Supangat, bekas mantra Klinik yang disinyalir berhaluan kiri. ${ }^{17}$

Dalam situasi seperti ini hubungan antar daerah menjadi tegang dan putus. Hal ini diakibatkan oleh lenyapnya hubungan yang komunikatif antar daerah. Tiap

\footnotetext{
${ }^{16}$ Lucas, op. cit., hlm. 225.

${ }^{17}$ Suryo, op. cit., hlm. 75
} 
daerah berusaha menjaga daerah masing-masing. Demikian pula hubungan dengan pemerintahan Karesidenan di Pekalongan juga menjadi putus dan penuh ketegangan. Lalu lintas terhambat, kareana di tiap perbatasan Kabupaten, terutama antara Kabupaten Pekalongan dengan daerah yang sedang bergolak itu, terdapat penjagaan ketat. Penduduk masing-masing daerah mencurigai orang yang masuk daerah lain. ${ }^{18}$

Satu-satunya cara untuk berhubungan dengan pusat ialah harus pergi ke Jakarta. Dua pemimpin Brebes, Kartohargo dan Maksum, mengunjungi kementrian sosial, meminta bantuan tentang bagaimana caranya menghentikan kekacauan di Kabupaten Brebes. Disana mereka diberi saran agar menghadap kementrian dalam negeri. Mreeka mendapat keterangan bahwa situasi Brebes hanya dapat dipecahkan oleh KNI setempat, karena pemerintah pusat belum mampu mengurusi situasi daerah. Mereka dilberi sepucuk surat agar menemui Gubernur Jawa Tengah di Semarang. Di kantor Gubernur di Semarang, Kartohargo dasn Maksum diberitahu agar menunggu instruksi adari atas.

Suatu jawaban untuk Kartohargo dan Maksum setelah mereka kembali ke Brebes adalah pengumuman politik dari pemerintah Jakarta, pengumuman yang dikeluarkan pada tanggal 27 oktober dan ditandatangani oleh Soekarno-Hatta, berisi tentang peringatan untuk rakyat agar tidak bertindak sendiri-sendiri, karena dapat menimbulkan anarki dan tumbangnya republik. ${ }^{19}$

Pejabat dan penguasa yang bersalah akan diturunkan dari jabatannya. Tuntutan-tuntutan harus diajukan melalui pemerintah atau perantaraan Komite

\footnotetext{
${ }^{18}$ Ibid.

${ }^{19}$ Lucas, op. cit., hlm. 227
} 
Nasional Daerah sebagai wakil rakyat sementara. Tentunya pengumuman ini bertentangan densagan kenyataan bahwa di Tiga Daerah aparat daerah setempat telah tercemar, dan KNI-nya tidak mempunyai kekuasaan untuk memainkan peranan seperti yang diharapkan oleh pusat.

Adalah menarik bahwa dalam situasi yang kacau dan kosong akan kekuasaan itu, maka kedatangan Widarta dan K. Mijaya sebagai utusan pribadi Menteri Penerangan sangat penting. Rupanya para pemimpin perjuangan seperti Kartohargo, yang sadar atau tidak sadar akan identitas politiknya, sedang berjuang menghadapi kelompok-kelompok lain yang merupakan saingan dalam mencapai tujuan revolusi. Mereka membawa kuasa pemerintah pusat, yang berarti membawa instruksi dari atas yang sudah ditunggu0tunggu itu. Instruksi tersebut adalah perintah untuk mewujudkan Badan Pekerja menggantikan KNI lama yang tidak berfungsi lagi. Badan pekerja itu merupakan hasil ide K.Mijaya, sedangkan pengaruh Widarta dapat dilihat dalam Front Persatuan yang dinamakan GBP3D, ${ }^{20}$ yang juga akan dibahas dalam bab ini.

\section{B. Metode Penelitian}

Metode penelitian berasal dari kata method dalam bahasa inggris yang berarti jalan atau cara. Secara estimologi, metode adalah masalah yang menguraikan tentang cara-cara atau jalan, petunjuk pelaksanaan secara teknis. Penelitian sejarah pada dasarnya terikat pada prosedur metode sejarah. Metode sejarah sendiri merupakan aturan serta prinsip sistematis dalam menpulkan sumber-sumber sejarah secara efektif dan menilainya secara kritis yang dibuat dalam bentuk tulisan. Metode yang digunakan peneliti dalam penulisan sejarah ini

${ }^{20}$ C. Van Dijk, "Rebellion Under Banner of Islam (The Darul Islam in Indonesia)", alih bahasa pustaka Utama Grafiti, Darul Islam Sebuah Pemberontakan. Jakarta: Pustaka Utama Grafiti, 1963, hlm. 122 
adalah metode penelitian menurut Kuntowijoyo. Adapun tahapan penelitian sejarah menurut Kuntowijoyo mempunyai lima tahap yaitu pemilihan topik, heuristik, verifikasi, interpretasi, dan penulisan.

\section{Munculnya Haluan Kiri dalam Revolusi}

Dalam konteks sejarah revolusi Indonesia, kehadiran haluan kiri selama berlangsungnya revolusi sosial di kabupaten Brebes, merupakan salah satu kekuatan politik yang penting, walaupun pengaruhnya tidak dapat diukur secara numeric. Tujuan pasti dari para pemimpinnya pada masa revolusi fisik, pada pertamanya ialah untuk dapat memegang kekuasaan potik. Mereka menempatkan hal itu sebagai prioritas pertama di atas seasgalanya termasuk juga pembagian $\operatorname{tanah.~}^{21}$

Sejarah tealah mencatat bahwa untuk sosialisme yang paling ampuh dan revolusioner adalah komunisme yang berupaya mempengaruhi dan mengatur gerakan-gerakan kemerdekaan. ${ }^{22}$ Kolonialisme yang kejam terahadap bangsa Indonesia, tealah melahirakan semangat anti kolonioal di pelbagai daerah. Timbul pula iklim marginal dalam masyarakat, yang sewaktu-waktu dapat melahirkan pemberontakan. Kombinasi antara ketidakpuasan sosial dan eksistensi pemimpin yang karismatik, merupakan landaasan kluat bagi banyaknya pemberontakan, khususnya yang bercorak :mesianik" (semacam gerakan Ratu Adil” yang banyak terjadi di Jawa dalam abad-abad ke-19 dan ke-20. Cabang-cabang sarekat Islam pun memperoleh kekuatan dari tatanan sosial semacam itu. Cabang-cabang itu

${ }^{21}$ Suryomiharjo, op. cit., hlm. 59

22 C. Wild, Peter Carey, Gelora Apai Revolusi: Sebuah Antologi Sejarah. Jakarta: PT.Gramedia, 1966, hlm. 26 
pula yang dijadikan ajang pertarungan sengit, dalam rangka menguasai sarekat Islam, antara para pemimpin muslimnya yang lebih ortodoks dan para anggota ISDV (Indische Social Democratic Vereniging), sebuah oraganisasi marxistis radikal yang didirikan pada tahun 1914, dan kemudian berubah menjadi PKI (Paratai Komunis Indonesia) pada tahun $1920 .^{23}$ pertarungan ini menyebabkan pecahnya Sarekat Islam pada tahun 1921, yang kemudian memungkinkan PKI untuk menguasai sebagian cabang Sarekat Islam. $^{24}$ Sealain itu, PKI pun memunculkan gerakan di pelbagai daerah, yang semata-mata memanfaatkan matris ketidak puasan sosial yang memang tidak pernah hilang. Polisi koloniel Belanda bekerja ekstra keras untuk mengontrol aktifitas PKI, namun tidak mapu mencegah pecahnya pemberontakan PKI pada tahun 1926 dan 1927. pemberontakan itu pada awalnya direncanakan PKI untuk melawan kolonielisme Belanda, dan dalam hal ini harus dipandang sebagai bagian yang sah dari pergerakan kebangsaan sebagai dasar sikap anti kolonielisme. ${ }^{25}$

Pemberontakan itu dapat segera ditumpas, dan PKI seperti juga sarikat Islam, menghilang dari pusat percaturn politik national. Khusus terhadap PKI, pemerintah Belanda tidak bertindak setengah-setengah, dan bahkan tidak sedikit pemimpin atau aktifis PKI diasingkan tampa ampun ke Digul di West New Guinea ( sekarang Irianjaya). Tetapi ditingkat daerah PKI tetap hidup, berkat kuatnya jaringan-jaringan organisasi buruh, sekolah-sekolah, dan kelompok

\footnotetext{
${ }^{23}$ Robert Bridson Cribb, "Jakarta in the Indonesia Revolution, 1945-1949”, alih bahasa Hasan Basri, Gejolak Revolusi di Jakarta 1945-1949, Pergulatanm antara Otonomi dan Hegemoni. Jakarta: Pustaka Utama Grafiti, 1990, hlm. 4

${ }^{24}$ Carey, op. cit., hlm. 29

${ }^{25}$ Abdurrachman Suryomiharjo, Kisah Pelajar Pejuang Daerah Tegal: Dari Bedil Kayu, Mitraliyur Kebangku Sekolah, 1983, hlm. 17.
} 
jawara. ${ }^{26}$ Namun mereka tidak menempatkan diri secara legal, tetapi bekerja melalui badan-badan yang legal seperti tidankanya dalam peristiwa tiga daerah. Dalam revolusi sosial, nama PKI tidak muncul, sehingga kegiatan itu seolah-olah merupakan tindakan perorangan yang mewakili gerakan nasionalisme.

Ada empat alasan mengapa PKI memilih tindakan illegal. Pertama, penghancuran PKI oleh Belanda setelah 1926 menghantui PKI bawah tanah dan dijadikanya peristiwa itu sebagai pelajaran sejarah. Kedua, kebanyakan PKI bawah tanah di tiga daerah, tokohnya seperti Widarta, K. Mijaya, Sarjio, Muroso berasal dari luar daerah dan bukan orang setempat. ${ }^{27}$ Ketiga, jika pra anggota PKI bawah tanah muncul sebagai pemimpin di tiga daerah, maka pagreh praja yang pro Belanda akan curiga karena kebanyakan pemimpin PKI adalah bekas buangan Digul keempat, terbatasnya kader PKI di tiga daerah, sehingga para kader inilah yang harus berusaha melaksanakan strategi Front persatuan dengan "nasionalisme Borjuis" melalui badan-badan yang ada sebagai sarana strateginya. Oleh karena itu PKI bawah tanah di tiga daerah mengambil strategi secara illegal.

Jika dirinci secara jelas, haluan kiri yang terlibat dalam peristiwa tiga daerah dapat disebut sebagai berikut.

Kelompok pertama yang tergolong dalam haluan kiri di tiga daerah, yaitu Veteran pemberontakan komunis 1926 eks-Digulis, termasuk di dalamnya pemimpin barisan pelopor dan badan pekerja di Tegal dan Brebes, AMRI Slawi dan GBP3D. mereka anti Fascisme Jepang dan tidak berkompromi dengan

${ }^{26}$ Cribb loc.cit.

27 Semasa penjajahan Belanda tokoh-tokoh komunis seperti Widarta dan K.Mijaya, adalah pelajar sekolah Islam ( Pesantren di luar wilayah karesidenan Pekalongan, yaitu di pesantren Tebu ireng, Jombang (Jawa timur), yang tersohor itu yang diasuh oleh seorang ulama tradisional yang terkenal yaitu Kyai Hasim Asy'ari. 
Belanda dan pengikutnya yaitu kalangan Feodal pangreh praja. Ketika proklamasi kemerdekaan dikumandangkan, merka menggunakan kesempatan untuk merombak struktur pemerintahan yang lama kea rah yang lebih demokratis. ${ }^{28}$

Kelompok kedua, yaitu kelompok sosialis yang berpengaruh di Tegal dan Brebes. Mereka mengaktifkan KNI sebagai wakil pemerintah sesudah proklamasi dan berusaha mempengaruhi sikap pagreh praja kea rah yang lebih mendukung republik baru. Kelompok sosialis mempunya saluran ke tingkat nasional lewat dua tokoh yang berasaldari Tegal. Yang pertama adalah Supeno, anggota partai sosialis dan badan pekerja komite nasional Indonesia pusat ( BPKNIP ) membela perkara tiga daerah di pengadilan Pekalongan pada awal 1947. tokoh kedua adalah Subagio Mangun Raharjo pemimpin PNI baru. ${ }^{29}$

Kelompok ketiga, di dalam haluan kiri yang menguasai GBP3D ialah PKI bawah tanah. Dengan hanya sejumlah kader yang berdisiplin, meraka tidak ada pilihan lain kecuali ikut serta dengan golongan-golongan yang dianggap merupaka unsur-unsur progresif dengan menggunakan KNI yang ada untuk melaksanakan prioritas pertama mereka, yaitu demokratisasi pemerintahan local. Dipadang dari sudut tujuan meraka, sukses-sukses yang mereka capai dengan jumlah kadernya yang kecil sungguh mengagumkan. Badan pekerja yang didirikan di Tegal dan Brebes, yang memerintah kedua kabupaten itu untuk selama enam minggu dibulan November dan Desember 1945, dapat bekerja dan berhasil. Para bupati yang terpilih secara tidak sengaja di Brebes dan Tegal berguna sebagai garis penghubung dengan golongan Islam. Terutama di Brebes, didirikanya badan

\footnotetext{
${ }^{28}$ Lucas, op. cit., hlm.295.

${ }^{29}$ Ibid.
} 
pekerja di tingkat kawedanan merupakan bukti suksesnya PKI dalam menjalankan strategi demokratisasi. ${ }^{30}$ Adapun lebih jauh lagi keterlibatan PKI dalam revolusi sosial akan dijelaskan dalam pembahasan berikutnya.

\section{Kedudukan Ulama dan Umat Islam dalam Revolusi Sosial}

Selain kaum kiri, elemen lain yang sangat penting yang juga bersaing berebut kekuasaan adalah golongan Islam. Mengapa kaum agama ikut arus revolusi dan apa cita-cita Islam wakti itu. Golongan Islam di Pekalongan terdapat dua aliran, Islam nasionalis dan Islam modernis Muhammadiyah. Mereka yang termasuk aliran pertama merupakan mayoritas di Tiga Daerah, dan merasa seabagi bagian dari tradisi anti kolonioal setempat yang kuat yang dirintis oleh Sarekat Islam (oraganisasi nasionalis pertama), yang kemudian dilanjutkan oleh penggantinya, Partai Sarekat Islam Indonesia (PSII). ${ }^{31}$ Meraka menghimpun pendukung dari kota dan desa, dan belakangan juga dari ulama, termasuk kyai Haji Satori, yang kemudian menjadi Bupati Brebes. ${ }^{32}$

Sejak jaman penjajahan Belanda, peran serta umat Islam di Kabupaten Brebes, Tegal, dan Pemalang, terlihat dari aktifitas mereka yang merupakan unsur sosial penting dalam masyarakat. Guru-guru agama, ulama dan kyai di desa sangat cepat mendapat kepercayaan dari rakyat terutama sejak dirasakan oleh rakyat

30 Suryomihajo, Peristiwa tiga daerah: suatu interpretasi sejarah: revolusi sosial menyambut proklamasi kemerdekaan. Prisma, No. 6. Jakarta: LP3ES, 1961, hlm.59.

${ }^{31}$ Audrey R.Kahin, loc. Cit.

${ }^{32}$ Yakub, Wawancara, 26 Maret 1999 
bahwa pangreh praja sebagai birokrat bentukan colonial telah berlaku sebagai "perpanjangan tangan penjajah.."33

Semenjak masuknya Islam ke iNdonesia, penduduk Kabupaten Brebes terkenal sangat giat dalam menjunjung tinggi agamanya. ${ }^{34}$ Mereka memusatkan kegiatannya didalam sekolah-sekolah Islam tradisional yang disebut pesantren, yang banyak tersebar dari Brebes sampai Pekalongan. ${ }^{35}$ Cirri-ciri utama dalam pesantren ini adalah masyarakat santri denagan kyai (guru agama desa) atau ulama sebagai pemimpinnya.

Pengalaman mereka sebelum Perang Dunia II dan sentimennya yang kuat menentang pangreh praja menghubungkan mereka dengan aspirasi revolusi sosial, yang berlawanan dengan sikap Muhammadiyah yang ada di Pekalongan. Beberapa orang diantaranya bergerak dalam kelompok-kelompok pemuda Islam sebelum Perang Dunia II. Semasa pendudukan Jepang kebanyakan dari mereka bekerja dalam banyak hal dengn tentara Jepang di jawatan urusan agama setempat, atau denagan dewan penasehat karesidenan, atau menjadi pemimpin masyumi, Hisbulah (lascar Masyumi), atau di Barisan Pelopor. ${ }^{36}$

Tokoh nasionalis Islam seperti K. H. Suja'I menganggap aliran kedua, yakni Muhammadiyah, sangat moderat dan pro pemerintah colonial. Kubu Muhammadiyah adalah masyarakat batik dan tekstil pekajangan, diselatan ibu kota karesidenan Pekalongan. Seluruh cabang Muhammadiyah telah didirikan oleh komunitas lengkap yang berorientasi dagang ini pada tahun 1923, dan hlm. 61

${ }^{33}$ W. F. Wertheim, Indonsian Society ini Transition, W. Van Hoeve, the hague, 1969,

\footnotetext{
${ }^{34}$ Soedarmo, op. cit., hlm. 29-34

${ }^{35}$ Suryo, op. cit., hlm. 78

${ }^{36}$ Audrey R. Kahin, op. cit., hlm. 42
} 
keuntungan dari koperasi batik Pekalongan yang didirisakan pada tahun1937 digunakan buat mendirikan sekolah adasar swasta berbahasa Belanda, yang dikenal dengan HIS Muhammadiyah. Diterimanya pendidikan Belanda ini mencerminkan perbedaan sikap diantara kedua kelompok Islam tersebut, karena kaum nasionalis Islam di Brebes tidak akan mengijinkan anak-anak mereka “duduk di bangku sekolah Belanda". Gaya hidup Pekajangan juga sangat berbeda daari mereka yang ada dikalangan komunitas Islam miskin di Kabupaten Brebes, dan juga tegal dan Pemalang.

Prinsip Islam tentang keadilan sosial sangat didambakan masyarakat pedesaan yang menderita akibat tingkat hidup yang jelek pada masa itu. ${ }^{37}$ Sarekat Islam Pekalongan sebagai golongan nasionalis Islam, sangat menentang terhadap kegiatan perdagangan pengusaha-penguasaha Cina yang berusaha menerobos kehidupan ekonomi pribumi. Tidak- jarang anggota-anggota sarekat Islam memandang aktivitas pengusaha Cina sebagai suatu gerakan rasialis yang harus dihadapi densagan kekerasan sehingga tidak jarang terjadi tindakan kekerasan seperti yang terjadi di Surakarta dan Surabaya. ${ }^{38}$

Pada akhirnya, kegiatan-kegiatan yang dilakukan para anggota Sarekat Islam pada akhirnya menjurus pada keinginan dibentuknya pemerintahan yang bersih dan berwibawa sesuai denagan syari'at Islam untuk menuju masyarakat yang adil dan bahagia. Hak sama rata berlaku bagi setiap orang, demikianlah tuntutan sarekat Islam Pekalongan. Sarekat Islam menganggap abdi penguasa yang korupsi harus digulingkan, dan tindakan ini harus dilakukan sampai

${ }^{37}$ Dijk, op. cit., hlm. 124

${ }^{38}$ R. V. Niel, "The Emergence of the Modern Indonesia Elite", alih bahasa Sahara Deliar Noer, Munculnya Elit Modern Indonesia, Jakarta: Dunia Pustaka Jaya, 1984, hlm. 126 
ketingkat kepala desa. Para penguasa yang korupsi itu diancam dan ditakuti dengan kekerasan, dan bila penguasa itu keluar karena takut maka calon dari Sarekat Islam siap menggantikannya. Pad masa revolusi soisal, aksi semacam ini dijadikan inspirasi dan merupakan perintis gerakan pembersihan para penguasa colonial. Aksi-aksi semacam ini ada diadalam tradisi protes masyarakat jawa sejak masa colonial. Nuansa ini mengekspresikan kegelisahan dan keinginan berontak kaum tani yang selama ini tertahan untuk melawan perubahan jaman. ${ }^{39}$

Ketika revolusi sosial meletus, gologan Islam merupakan salah satu kekuatan sosial yang ikut berperan didalamnya. Merreka menyokong revolusi dengan sepenuh hati. Namun ketika revolusi mulai menyimpang dari arah yang sebenarnya, dengan tindakan-tindaknnya yang radikal dsan mrnghina umat Islam, mak umat Islam di Tiga Daerah menyadari kekeliruanya. Dengan serta merta mereka menarik diri dan bahkan berdiri sebagai elit tandingan, bahu membahu bersama TKR dn Muhammadiyah dan berhasil menghentikan pemrintah revolusioner.

Ketika revolusi masih merupakan gerakan murini rakyat, golongan Islam bersama-sama dengan rakyat dan pemuda turut melakukan aksi pendaulatan terhadap pangreh praja yang korupsi itu. Kaum ulama biasanya berperan sebagai pembatas emosional penduiduk. Artinya apabila masyarakat melakukan aksi pendaulatan dan pembagian kekayaan pangreh praja yang diadaulatnya, maka kaum ulama berperan sebagai pengawas agar barang-barang yang dibagikan

${ }^{39}$ H. J. Benda, "The Creecent and the Ricing Sun: Indonesian Islam Under the Japanese Occupation, 1941-1945 alih bahasa Daniel Dhakidae, Bulan Sabit dan Matahari Terbit: Islam Indonesia pada masa Pendududkan Jepang. Jakarta: Pustaka Jaya, 1985, hlm. 66 
hanaya barang-barang yang diduga hasil korupsi dan mencegah tindak sewenangwenang rakyat.

Di daerah-daerah yang didominasi golongan Islam, baiasanya penggantian 1;urah relatif berlangsungdengan tertib, sepeti misalnya yang terjadi di Tanjung, Kersana, Losari, Banjarharjo, Bumiayu, dan Salem. Di Kecamatan Salem, hamp[ir semua lurah diganti sampai ke RT-RTnya. Sedangkan penggantinya hamper seratus persen dsari golongan Islam Nasionalis., karena kecamatan Slaem sel;uruh masyarakatnya menganut agama Islam. ${ }^{40}$

Bagaimanakah golongan Islam nasionalis dan golongan kiri saling bereaksi pada masa itu. Pada mulanya, Islam nasionalis bersedia bekerjasama dengan kaum kiri dalam mempertahankan kemerdeakaan Indonesia dan kaum komunis menganggap kekuatan Islam dapat diajak bekerja sama. Dalam kenyataannya penderitaan rakyat telah mempersatukan semua golongan di pedesaan. Di desa-desa, kelompok NU mendapat tekanan ekonomi, sedangkan santri melarat di kota kabupaten tidak dapat masuk sekolah Belanda karena tidak mempunyai modal. Golongan Islam nasionalis K. H. Abu Suja'I dan kyai-kyai desa bersenyawa dengan rakyat melarat di kota maupun di desa, bahkan lebih bersenyawa jika dibandingakan dengan badan-bandan pekerja atau GBP3D-nya golongan kiri. Sedangkan Muhammadiyah, seperti halnya bupati Brebes K. H. Syatori lebih dekat pad golongan atas, priyayi atau pangreh praja. Golongan Muhammadiyah tiadak terganggu denagan adanya modal asing di karesidenan pekalongan sebelum perang dan mereka masih dapat mempertahankan status

\footnotetext{
${ }^{40}$ Darwa al-Tirta, Wawancara, 3 April 1999. Beliau sendiri pad masa pendudukan Jepang menjabat sebagai kumicho, dn ketika revolusi bergolak jabatannya diganti oleh kaum revolusioner.
} 
ekonominya di masa pendudukan Jepang. Pada masa revolusi, golongan Muhammadiyah klurang dapat memahami bahwa masalah kemiskinan santrisantri di Tiga daerah itu erat hubungannya dengan masalah yang dimilki oleh kaum revolusioner di Tiga Daerah.

Pemanfaatan golongan Islam oleh kelompok kiri lebih jelas lagi dengan adanya pengangkatan bupati-bupati baru yang berasal dari golongan Islam oleh Badan Pekerja di Brebes dan Tegal. K. H. Syatori diangkat sebagai Bupati Tegal. $^{41}$

Sebenarnya pengangakatan itu dimaksudkan agar golonagan islam terus memberi simpati terhadap pemerintahan revolusioner. Pemegang peranan sebenarnya dalam pemreintahan adalah tetap Badan Pekerja. Tugas Bupati semata-mata hanyalah menandatangani keputusan-keputusan yang dibuat oleh Badan Pekerja. ${ }^{42}$ Oleh sebab itulah golongan kiri merasa perlu adanya kerjasama denagan golongan nasionalis Islam.

Sebagian kaum radikal memandang bahwa pengangkatan bupati-bupati dan kepala daerah dari kelompok Islam, akan menghindari pertentangan antara kaum kiri dan Islam. Namun ketika pemerintahan revolusioner berdiri pada tanggal 11 Desember 1945, golongan Islam mulai sadar bahwa gerakan yang mereka lakukan amat membahayakan Negara.

Sebenarnya, tujuan utama perjuangan kemerdekaan menurut golongan Islam adalah bersatu dalam menghadapai kembalinya tentara Belanda. Namun ternyata balas dendam telah menggantikan tujuan perjuangan, karena siapa saja

\footnotetext{
${ }^{41}$ Yakub, Wawancara, 26 Maret 1999

${ }^{42}$ Lucas, op. cit., hlm. 240
} 
yang sebelumnya dianggap membantu kolonial dibunuh. ${ }^{43}$ Perlakuan kasar yang dilakukan oleh pasukan pengawal Tiga Daerah terhadap masyarakat menimbulkan rasa muak golongan Islam, karena tindakannya yang mirip denagan apa yang pernah dilakukan oleh kolonial Jepang.

Pada tanggal 13 Desember 1945, golongan Islam menuntut pembubaran pemerintahan revolusioner. Tekad kelompok Islam didukung sepenuhnya oleh TKR Pekalongan. Hal ini dapat dimaklumi mengingat para pemimpin TKR kebanyakan berasal dari ulama Islam. Fenomena inilah yang menyeret pemerintahan revolusioner ke tiang gantungan sejarah, yang hanya bertahan beberapa hari saja setelah pembentukannya.

\section{E. Kesimpulan}

Revolusi sosial di kabupaten Brebes pada tahun 1945, yang merupaka bagian integral dari Peristiwa Tiga Daerah bi Karesidenan Pekalongan, ternyata bukanlah suatu bentuk kerusuhan semata-mata criminal sifatnya. Tetapi lebih dari itu, ia merupakan suatu jenis reaksi terhadap situasi lingkungan yang tenagah berubah. Proklamasi kemerdekaan dipandang sebagai lambang kebebasan dari segala ikatan. Ikatan politik kolonial, ikatan sosial ekonomi, adan cultural yang selama masa penjajahan membelenggunya dianggap harus melepas semuanya. Personifikasi sifat-sifat kolonial dan feudal sering dicari dalam diri pelaksananya. Dalam hal ini adalah pangreh praja dan pejabat pemerintah sering mewakilinya. Adalah wajar apabila pangreh praja dianggap sebagai personifikasi seagala sifat

\footnotetext{
${ }^{43}$ Ibid.
} 
pemerintah kolonial, karena memang yang paling dekat dapat dikenali dalam lingkungan terbatasnya.

Antipati terhadap pangreh praja ini bersumber pad tindakan-tindakan mereka sebagai pelaksana pemerintahan yang korup dan sewenang-wenang. Berbagai sistem pemerintahan pad penjajahan yang langsung mengganggu hak milik tanah dn hasilnya merupakan sumber latent bagi timbulnya situasi yang konflik. Hal ini bisa dipahami karena tanah dan tanaman diatasnya merupakan sumber vital bagi kehidupan. Konflik-konflik di seluruh wlayah kabupaten pada masa itu juga bersumber pada pemilikan tanah yang dipergunakan oleh orang atau lembaga lain tanpa imbalan yang seimabang. Dengan kata lain, apabila prinsip kesimbangan terganggu, maka terjadilah konflik. Jika ini ditinjau dari pendekatan konflik, maka revolusi sosial di Kabupaten Brebes adalah suatu peristiwa yang sah dan wajar muncul di bumi Indonesia ini. Bahkan kehadiran Hitler sekalipun adalah sah, meskipun kelahirannya ditangisi oleh seluruh dunia.

Sumber konflik juga sering ditemui dalam sikap yang kurang tanggap terhdap situasi. Diasdalam perubahan yang ceapat, dikehendaki kecepatan dalam menyesuaikan dengan tuntutan situasi baru. Kecontalan dalam menanggapi tuntutannya yang beru akan menempatkan diri kedalam situasi konflik, karena ada dalam perbedaan nilai atau norma yang berbeda. Untuk memberi makna yang lebih mendalam tentang revolusi sosial di Kabupaten Brebes terhadap peristiwa Tiga Daerah, bahkan pada revolusi nasional secara keseluruahan, maka perlulah kiranya dianalisis dari beberapa segi serta menkaitkannya dengan hipotesa tentang penelitian ini. 
Di kabupaten Brebes, sekali elit birokrasi dicopot maka tiga kelompok bersaing berebut kekuasaan, yaitu PKI dengan Front rakyatnya, golongan Islam yang sudah mapan, dan tentara. Kelompok-kelompok yang persepsinyas berbeda ini memang menghendaki sifat perjuangan yang mereka pimpin berlain-lainan pula, mencerminkan latar belakang, komposisi, dan tujuan masing-masing. Kelompok Pertama adalah kaum komunis setempat, yang pada tanggal 16 Nopember mendirikan Front Rakyat yang disebut Gabungan Badan Perjuangan Tiga Daerah (GBP3D). dengan bermarkas di kantor Partai Sosialis Amir Syarifudin cabang Tegal, prioritas utama front ini adalah menggantikan seluruh pejabat lama, yang tidak hanya di tingakat Kabupaten, tetapi juga di tingkat karesidenan.

Kelompok kedua yang bersaing berebut kekuasaan adalah golongan Islam. Ini pun ada dua aliran, Islam Nasionalis dan Islam Modernis, Muhammadiyah. Mereka yang termasuk aliran pertama merupakan mayoritas di Kabupaten Brebes, dan merasa seabagai bagian dari tradisi anti kolonial setempat yang kuat yang dirintis oleh sarekat Islam, yang kemudian dilanjutkan oleh Parata Sarekat Islam Indonesia (PSII). Mereka menghimpun pendukung dari kota dan desa. Meskipun Bupati Brebes, K.H. Syatori berasal dari golongan Islam Modernis, namun karena masyarakat kabupaten Brebes mayoritas dari golongan NU, maka golongan Islam nasionalis tetap mendominasi pemerintahan dari tingkat kawedanan sampai ke tingkat desa. Kelompok ketiga yang juga ikut bersaing adalah tentara. Untuk memahami mengapa TKR melancarkan kontra revolusi dengan jalan mengadakan persekutuan denagan Islam Pekajangan untuk 
melawan Front rakyat, kiranya dapat diceramati dari latar belakang sosial dan kepemimpinannya serta kondisi ekonomi para anggota Peta semasa pendudukan Jepang. Semua perwira resimen Peta di Pekalongan berasal dari batalyon Peta bentukan pemreintah militer Jepang. Kebanyakan komandan kompi Peta telah direkrut dari keluaraga elit birokrasi dan ada yang telah bekerja sebagai camat sebelum Jepang masuk. Setelah adanya maklumat Presiden Soekarno pasd tanggal 5 Oktober 1945 tentang pembentukan TKR, maka para anggota TKR Pekalongan adalah mayoritas bekas anggota Peta. Jadi jelslah dalam lingkup lokal ini TKR Pekalongan mempunyai latar belakang sosial ekonomi yang berbeda dengan rakyat.

\section{Daftar Pustaka}

Abdulah, Taufik dan Abdurahman Suryomiharjo, 1985. Ilmu Sejarah dan Hisoriografi Arah dan Prespektif. Jakarta: Gramedia

Benda, H.J, 1985 "The Crescent and the Rising Sun: Indonesia Islan The Under the Japanese Occupation, 1942-1945", alih bahasa Daniel Dakhidae, Bulan Sabit dan Matahari Terbit:Islam Indonesia Dalam masa Pendudukan Jepang, Jakarta: Pustaka jaya.

Cribb, Robert Bridson, 1990. "Jkarta In the revolution, 1945-1949" alih bahasa pustaka utama graffiti, gejolak revolusi di Jakarta 1945-1949: pergulatan antara otnomi dan hegemoni. Jakarta; pustaka utama graffiti.

Dijk, C. Van., 1963. " Rebellion Under the Banner of Islam: The Darul Islam in Indonesia, alih bahasa Pustaka Utama Grafiti, Darul Islam Sebuah Pemberontakan. Jakarta: Temprint.

---------, 1981. "Wajah Revolusi Indonesia Dipandang dari Perspktifisme Struktural". Prisma Nomer 8. Jakarta : LP3ES.

Kodam VII Diponegoro, 1986. Sedjarah TNI-AD, Sirnaning Jakso Katon Gapuraning Ratu, Semarang: Dinas Sejarah Militer Kodam VII/ Diponegoro.

Lucas, Anton E., 1989. “The Bamboo Spear Pierces The Payung: The Revolution Againnst the Bureau ccratic Elite in North Central Java in 1945", alih bahasa pustaka Utama Grafiti, Peristiwa Tia Daerah: Revolusi dalam Revolusi. Jakarta: Pustaka Utama Grafiti. 
Niel, R. V., 1984. "The Emergence of the Modern Indonesia Elite”, alih bahasa Sahara Deliar Noer, Munculnya Elit Modern Indonesia, Jakarta: Dunia Pustaka Jaya.

Suryomihardjo, Abdurrachman, 1961. Peristiwa Tiga Daerah Suatu Interpretasi Sejarah : Revolusi Sosial Menyambut Proklamasi Kemerdekaan. Prisma, No. 8. Jakarta: LP3ES.

Wertheim, W. F., 1969. Indonesian Society ini Transition, W. Van Hoeve, the Hague. 